\title{
Fake News in Social Media: A Study on the Usage of Social Media in Palakkad City during Kerala Flood
}

Mr. K. B. Sankaranarayanan", Mr. Paul T. Benziker

"Assistant” Professor, Department of Visual Communication, Nehru Arts and Science College, Coimbatore, Tamil Nadu, India

DOI: $10.36347 /$ sjahss.2020.v08i04.002

| Received: 21.03.2020 | Accepted: 30.03.2020 | Published: 07.04.2020

*Corresponding author: Mr. K. B. Sankaranarayanan

Abstract

Original Research Article

The paper examines the acceptance level and attitude towards fake news propagated through social media among common people. Social Media now a day has become one of the most easily accessible infotainment medium than Television. In Social media we can create, spread and gather fake news easily than any other media. "Fake news" is defined as to be news articles that are intentionally and verifiably false, and could mislead readers (Hunt Allcott and Matthew Gentzkow: Social Media and Fake News in the 2016 Election). From many studies, the youth is one among them involved in creating and spreading this kind of news. There is change in accessing the news from an authentic medium rather than from an easily accessible medium regardless of the source. With the social media acting as a vital but not foremost source of news, On an average a student is spending more than 4 hours in face book, with just over half of those who recalled seeing them repeatedly make them to believe what they consume as fake news, and discuss within their peer group or any other for authenticity. The Researcher discusses how the common man gets information on certain events (news) and why they prefer these certain formats to get informed. The study progress through the content analysis of the fake news posted and shared through social media during the emergency time of kerala flood in Palakkad (City) dist. The researcher selected 50 news posted in social media during the months of Aug $1^{\text {st }}$ to Nov $30^{\text {th }}$ 2018.The study reveals that there is no control over social media by the government. Some people who are less informed uses social media as a medium to post and spread the fake news. Proper education on the use of social media among youth and artificial intelligence can be practiced and applied to stop fake news being spread through social media.

Keywords: Fake News, Social media, Fake, misinformation.

Copyright @ 2020: This is an open-access article distributed under the terms of the Creative Commons Attribution license which permits unrestricted use, distribution, and reproduction in any medium for non-commercial use (NonCommercial, or CC-BY-NC) provided the original author and source are credited.

\section{INTRODUCTION}

Fake news is a type of propaganda that consists of deliberate misinformation or hoaxes spread through traditional print and broadcast news media or online social media [1]. Fake news stories have played an outer role in many countries, especially in India during periods of emergency. Some countries had to ban social media during these chaotic times. Since its introduction the social media has brought a new dimension in delivering the false information to the masses [2].

There are several reasons to think that fake news is of growing importance. The main reason behind that is that the barriers to access and enter in the media business have dropped steeply, because it is now easy to set up websites and monetize web content through advertising platforms. Second, social media use has risen sharply: in 2016, active Face book users per month reached 1.8 billion and Twitter's approached 400 million. Social media are well-matched for fake news propagation [3].

\section{Types of News}

According to the French, News is a certain kind of information on any event that has occurred or going to occur. In this research the data were categorized into three categories [4]:

- Misleading content ("misleading use of information to frame an issue or an individual").

- Fabricated news - completely fictitious facts or events (e.g., stories related to disease negation).

- False context ("when genuine content is shared with false contextual information"). 
Though, the ultimate data were dichotomized as true or false news due to the lack of vagueness of categorizing data into different types. The genuineness of news was judged by collecting the news from authentic face book pages and newsletters of government bodies.

Two main motives behind fake news are financial and ideological. The problem is many people choose the off beam options based on misinformation or they continue to uphold invalid beliefs and prejudiced opinions, accepted as system of belief, despite undeniable evidence to the contrary [5]. First, they make no investment in accurate reporting, so their underlying signals are uncorrelated with the true state. Second, they do not attempt to build a long-term reputation for quality, but rather maximize the short-run profits from attracting clicks in an initial period [6].

Twitter has proposed a request to the public for a set of current health issues so as to ensure healthy conversation in their platform which in turn would prevent issues such as misinformation, echo chambers, abuse or spam [7].

\section{Models of Fake News}

Many types of fake news are spread over social media where each one uses separate kind of techniques to catch the attention of masses. First, consumers who mistake a fake outlet for a legitimate one have less-accurate beliefs and are worse off for that reason. Second, these less-accurate beliefs may reduce positive social externalities, undermining the ability of the democratic process to select high-quality candidates. Third, patrons may also become more doubtful of genuine news producers, to the extent that they become hard to distinguish from fake news producers. Fourth, these effects may be reinforced in equilibrium by supply-side responses: a reduced demand for high-precision, low-bias reporting will reduce the incentives to invest in accurate reporting and truthfully report signals [3].

\section{Cause of Fake news}

There might be many reasons for fake news to be created by a person or a group. But many of us don't comprehend that much of the information they are going through can be tainted due to their own misinterpretation and human fault. Without reading the headlines and date or times, and delusion of the information can cause fake news to spread within a small period of time. Fake news can also be the misrepresentation of any irrelevant breaking news article that is either unfinished or previous news that may be professed to current day the reader is into. Once they are shared a number of times by people and go viral, they are believed to be truthful [7].

\section{METHODOLOGY}

\section{Sampling Technique}

The method used in this study is simple content analysis. 50 fake news that was spread during the time of Kerala flood in palakkad town was taken for content analysis.

\section{Data Collection}

The data was collected from authentic sources like official page of Kerala police, Indian Army, District collectors official face book page etc. The source or origin of fake news spread over that time was not identified but the news were spread and delude the public at emergency period. In our material, collected from those period $61 \%$ of the posts were assessed as fake news.

\section{Data Analysis}

Fake news spread in social media during Kerala flood from Aug 2018 to Nov 2018?

Int: It is interpreted that 64 fake news and 21 genuine news were identified (Randomly) from social media during that period. Which means that about $32 \%$ of genuine news was only posted against the fake news that were spread through social media.

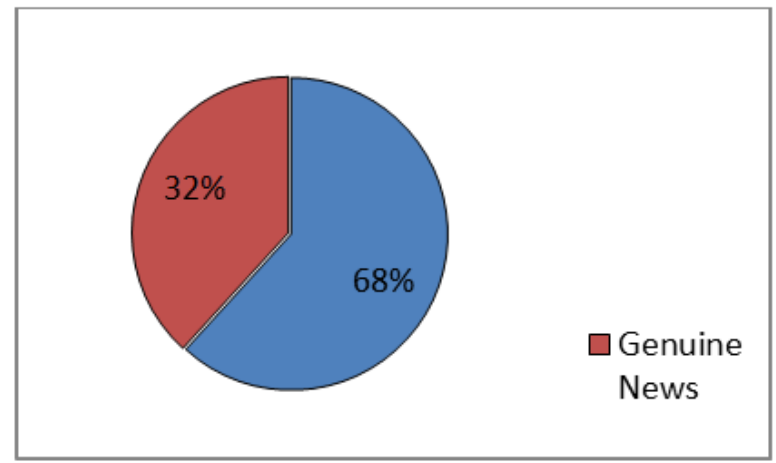

No of fake news spread through different social media out of selected 50 fake news.?

Int: It is interpreted that 26 fake news in face book, 11 in whats app, 9 in twitter, and 4 in other social media were posted. This means that about $52 \%$ fake news was spread through face book platform and $22 \%$ through twitter.

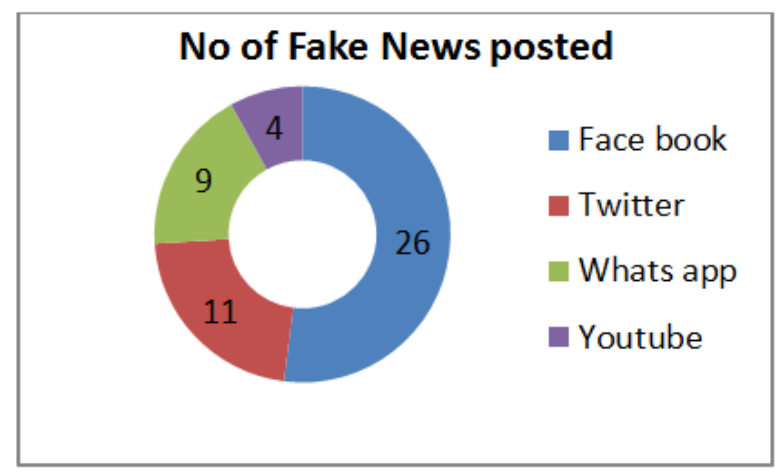




\section{Fake news on KSEB alert}

Int: It's found that this news was initially spread through Whats app and later went viral within minutes when it was posted by some anonymous user in face book and twitter. It was shared 929 times and $1.4 \mathrm{k}$ likes are found in face book post. This means that about $61 \%$ of likes and $54 \%$ of shares were on face book compared to twitter.

\begin{tabular}{|l|l|l|}
\hline Fake news on KSEB & Face Book & Twitter \\
\cline { 2 - 3 } ALERT & $\begin{array}{l}\mathbf{7 8} \\
\text { (Random) }\end{array}$ & $\begin{array}{l}\mathbf{5 9} \\
\text { (Random) }\end{array}$ \\
\hline No of Likes (Aggregate) & 1456 & 903 \\
\hline $\begin{array}{l}\text { No of shares /Re-tweets } \\
\text { (Aggregate) }\end{array}$ & 929 & 762 \\
\hline No of Comments & 32 & 19 \\
\hline
\end{tabular}

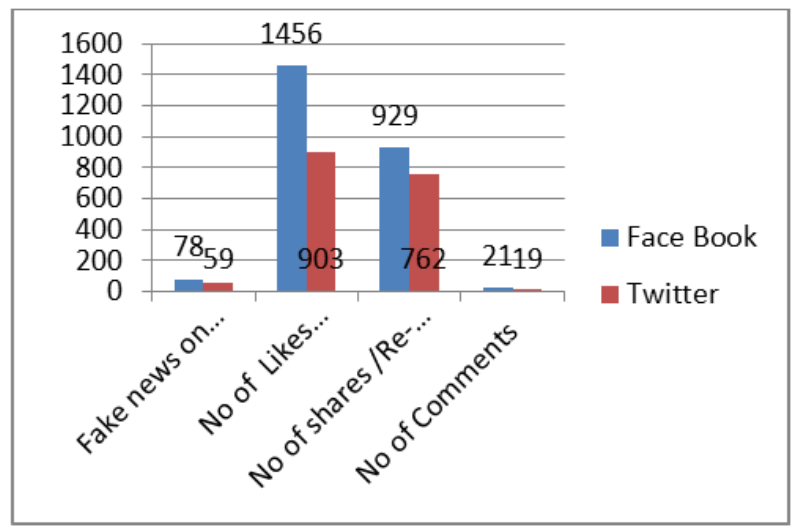

Genuine news against the fake KSEB alert on official social media pages of KSEB and Kerala police

Int: It is interrupted that genuine news has also spread through the social media suddenly even after the fake news was posted. It means that $72 \%$ of genuine news were spread more in face book.

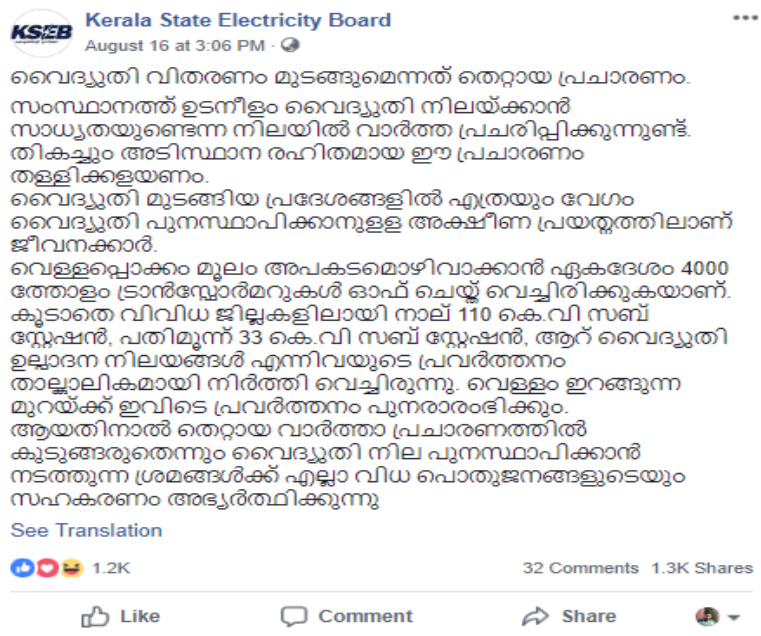

\begin{tabular}{|l|l|l|}
\hline $\begin{array}{l}\text { Genuine news on Official } \\
\text { page of KSEB }\end{array}$ & Face book & $\begin{array}{l}\text { Twitter } \\
\text { (Random) }\end{array}$ \\
\hline No of Likes (Aggregate) & $1.2 \mathrm{~K}$ & 450 \\
\hline No of shares /Re-tweets & $1.3 \mathrm{~K}$ & 365 \\
\hline No of Comments & 32 & 11 \\
\hline
\end{tabular}

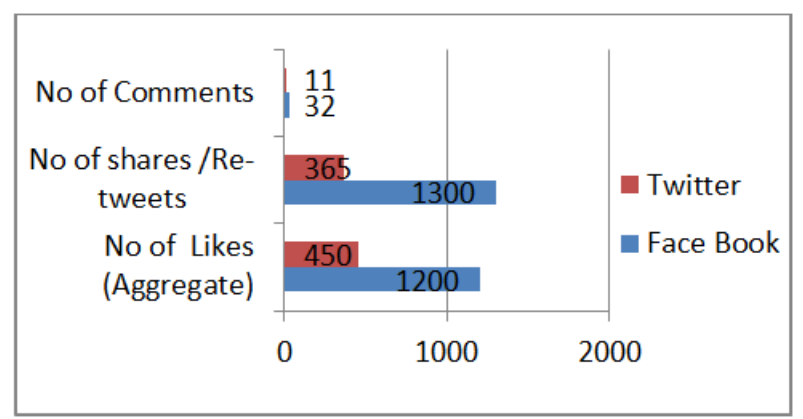

No of Fake news on mullaperiyar dam using different medium of communication

Int: It is interrupted that Face book post $(46 \%)$ with pictures has been posted and shared many times compared to other mediums in which $(34 \%)$ of news with only text was shared.

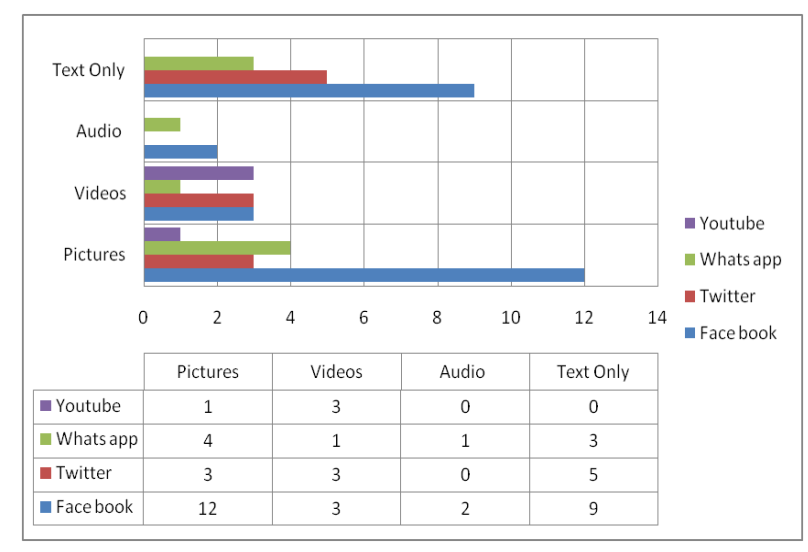

\section{FINDING}

1. The majority of news that was shared or forwarded was fake

2. Majority of news was posted from unidentified source and the people were sharing/forwarding without knowing the genuineness of news.

3. Only few percent of news were genuine and was shared less among the public when compared to fake news.

4. A Majority of the news spread was accompanied with pictures/Videos in order make the people to accept as true news.

5. Only few people were caught by the govt/police for spreading the fake news since the source / origin of news was unable to identify as soon as the news is being spread. 


\section{CONCLUSION}

The velocity of fake news being spread is unimaginable since the development of mobile phones and internet accessibility and its speed. Through the systematic content analysis the study reveals that people are sharing the news without knowing the source of origin or the authenticity of the news forwarded. Since it's an emergency period the people are also getting panic by seeing these kind of news and they are either forwarding/sharing this news through their social media accounts or informing others or their loved ones over phone. The study also reveals that the government has no control over social networks during this emergency period and only with the help of cyber cell higher government officials should take necessary steps to control and eradicate these kind of news being spread in social medias during emergency period.

Further in future an in-depth study with data mining is needed to find out the source of news, and why its shared in particular social medias and with what intention they are sharing.

\section{LIMITATIONS OF THE STUDY}

The researchers were not able to find the exact no of shares or likes that was posted by different people on different social media. It can be only achieved with the help of data mining software's.

\section{REFERENCES}

1. Dharshanram R, Madan Kumar PD, Iyapparaj P. Spread of health-related fake news in Tamil social media - A pilot study. Journal Global Oral Health 2018;1(1):21-24.

2. Pricacy Issues in Social Media "Fake News and Social Media" - Erdal Ozkaya - Dubai, United Arab Emirates.

3. Social Media and Fake News in the 2016 Election Hunt Allcott and Matthew Gentzkow

4. Robinson PG. Editorial: Logos, ethos and pathos: Whither academia and public health in a post-truth world? Community Dent Health, 2018;35:3-4.

5. Bode L, Vraga EK. See something, say something: Correction of global health misinformation on social media. Health Commun, 2018;33:1131-40.

6. Merlo C. Millonario Negocio Fake News. Univision Noticias. Available from: https://www.univision.com/noticias/americalatina/el-millonario-negocio-detras-de-los-sitiosde-fake-news-enmexico.

7. Ozkaya E. Privacy Issues in Social Media, "Fake News and Social Media”. 2017. 